\title{
Nesiotites rafelinensis sp. nov., the earliest shrew (Mammalia, Soricidae) from the Balearic Islands, Spain
}

\author{
Juan Rofes, Pere Bover, Gloria Cuenca-Bescós, and Josep Antoni Alcover
}

\begin{abstract}
This paper describes a new species of shrew from a fossiliferous bone breccia near to Caló den Rafelino (Mallorca, Spain). The site is stratigraphically and palaeontologically dated to the earliest Early Pliocene (MN13-14). Nesiotites rafelinensis sp. nov. (Mammalia, Soricidae) is arguably the earliest representative of the Nesiotites known to date, a clade restricted to the Balearic Islands. The new species combines primitive dental traits with a relatively large size. The primitive features relate $N$. rafelinensis more with Asoriculus gibberodon, the possible ancestor of Nesiotites, than any other representative of the genus. The large size interrupts a, otherwise, regular trend of increase of size from the comparatively small $A$. gibberodon to the recent very large $N$. hidalgo. The faunal assemblage of Caló den Rafelino represents the earliest evidence of the fauna that arrived to the Mallorca Island during the Messinian Salinity Crisis.
\end{abstract}

Juan Rofes. Departamento de Estratigrafía y Paleontología, Facultad de Ciencia y Tecnología, Universidad del País Vasco. Sarriena s/n, 48940 Leioa, Spain and Grupo Aragosaurus-IUCA, Área de Paleontología, Departamento de Ciencias de la Tierra, Universidad de Zaragoza, 50009 Zaragoza, Spain.. juan.rofes@ehu.es

Pere Bover. Institut Mediterrani d'Estudis Avançats, Cr Miquel Marqués 21, 07190 Esporles, Mallorca, Balearic Islands

and

Research Associate, Division of Vertebrate Zoology/Mammalogy, American Museum of Natural History, Central Park West at 79th Street, 10024 New York, USA. perebover@imedea.uib-csic.es

Gloria Cuenca-Bescós. Grupo Aragosaurus-IUCA, Área de Paleontología, Departamento de Ciencias de la Tierra, Universidad de Zaragoza, 50009 Zaragoza, Spain. cuencag@unizar.es

Josep Antoni Alcover. Institut Mediterrani d'Estudis Avançats, Cr Miquel Marqués 21, 07190 Esporles, Mallorca, Balearic Islands, Spain. jaalcover@imedea.uib-csic.es

KEYWORDS: New species; anatomy; Caló den Rafelino; Mallorca; Pliocene; Messinian salinity crisis 


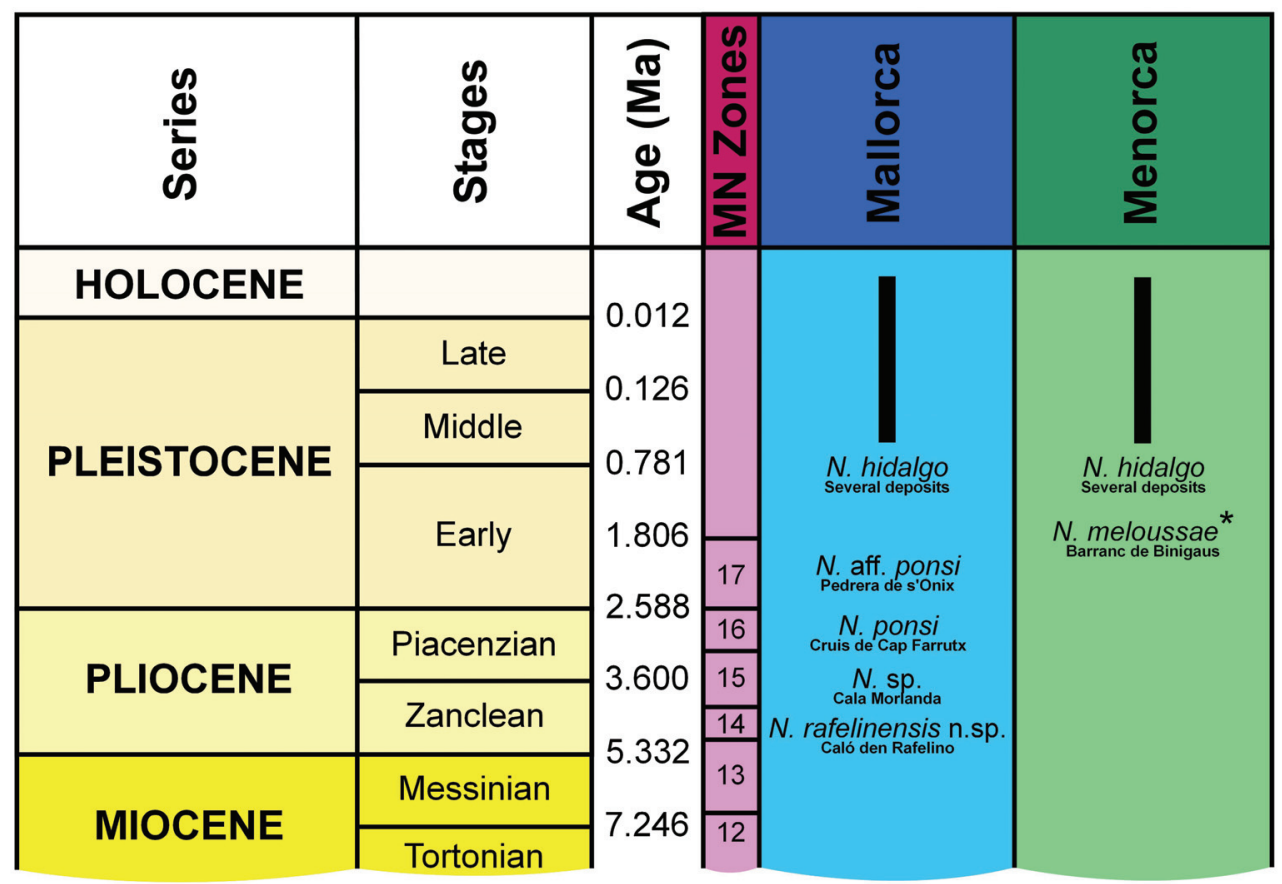

FIGURE 1. Chronological frame of the Nesiotites species described in the Balearic Islands. The Quaternary chronology follows Gibbard et al. (2010). MN zones according to Agustí et al. (2001). (*): The taxonomical identity of $N$. meloussae and the presence of a separate phylogenetic lineage of the genus in Menorca are controversial and are currently under discussion.

\section{INTRODUCTION}

The genus Nesiotites was erected in 1945 by Dorothea M.A. Bate to include three Late Pleistocene species of shrews (Mammalia, Soricidae): Nesiotites hidalgo Bate, 1945, from Mallorca and Menorca, N. corsicanus Bate, 1945, from Corsica, and $N$. similis (Hensel, 1855) from Sardinia. This latter species was initially assigned to Sorex.

The oldest remains of Nesiotites, described as Nesiotites sp., came from Cala Morlanda (Mallorca, Pons-Moyà, 1990), a site of nearly middle Pliocene age. The location of this material is unknown. Pons-Moyà (1990) indicates that the specimens were slightly smaller than those of $N$. ponsi from the Late Pliocene of Mallorca (Reumer, 1979) (see Figure 1). This latter species differs from $N$. hidalgo mainly by its small size and by the presence of a fourth antemolar in all individuals. Pons-Moyà and Moyà-Solà (1980) described Nesiotites meloussae from Menorca. This species, found at the Early Pleistocene site of Binigaus, has a general size intermediate between $N$. hidalgo and $N$. ponsi. The authors erected the new species on the basis of morphological characters that made them to postulate the existence of a hypothetic independent phyletic lineage of the genus on Menorca.

Reumer (1981) described also an intermediate form from Pedrera de s'Ònix at the Early Pleistocene of Mallorca, which was referred as Nesiotites ex. interc. ponsi-hidalgo. This form has been referred also as Nesiotites aff. ponsi by Alcover et al. (1981) and other authors. Reumer (1982) rejected the existence of an endemic lineage on Menorca and considers $N$. meloussae as a valid name for his previously named $N$. ex interc. ponsi-hidalgo. Nesiotites aff. ponsi will be used in this paper to name the material from Pedrera de s'Ònix, as its specific identity remains unclear (see Pons-Monjo et al., 2010).

It has been generally accepted that the most likely ancestor of Nesiotites was the genus Episoriculus Ellerman and Morrison-Scott, 1951 (Reumer, 1980). Hutterer (1994) transferred all European fossil Episoriculus to the genus Asoriculus Kretzoi, 1959, an opinion widely accepted by scholars. Reumer (1998) considered Episoriculus a subgenus of Soriculus Blyth, 1854, differentiating it from Asoriculus.

The phylogenetic analysis performed by Rofes and Cuenca-Bescós (2009) showed that the 


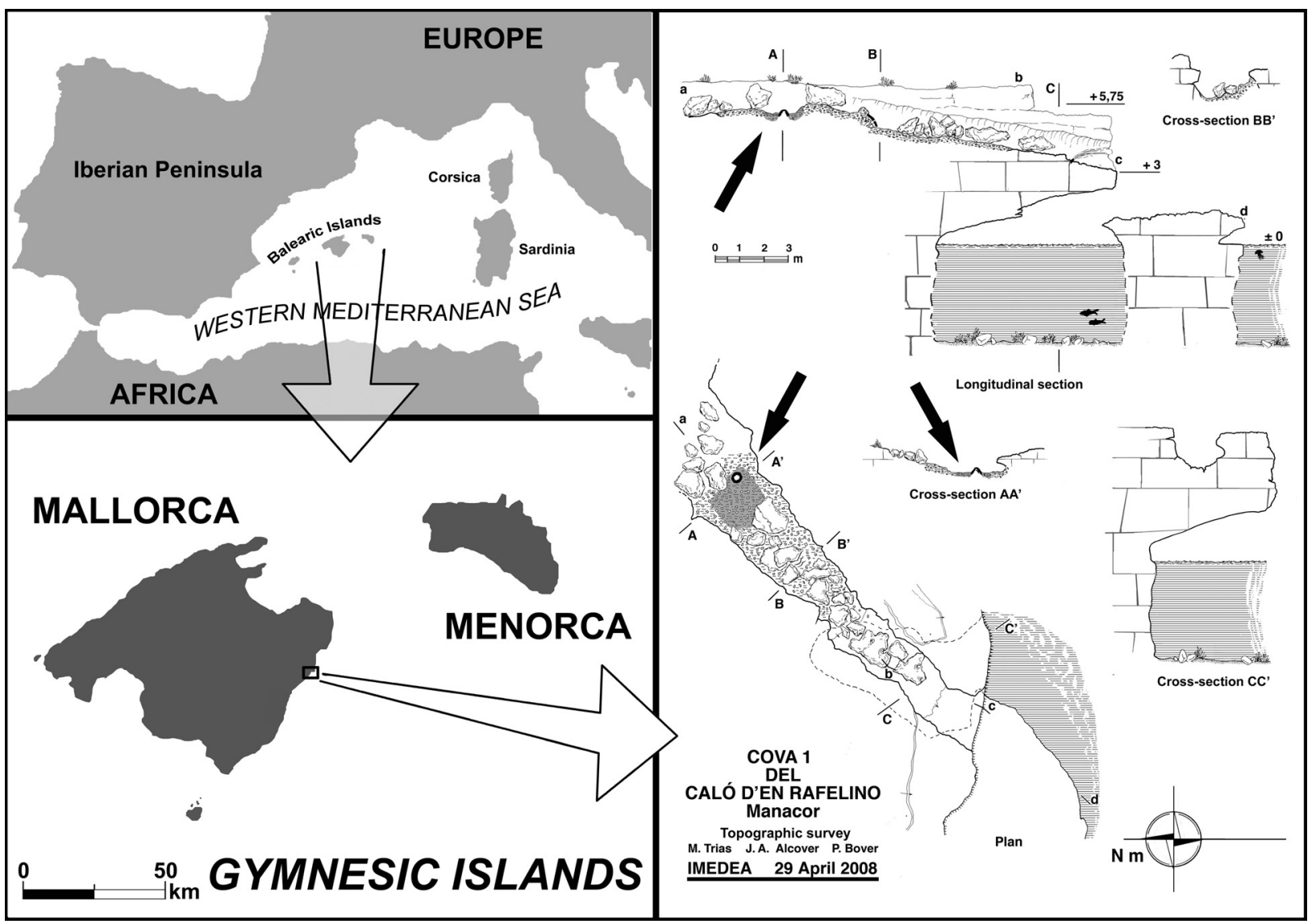

FIGURE 2. Location map (left) and topographic survey (right) of the palaeontological deposit from Caló den Rafelino. Arrows and grey colored zone indicate the exact location of the fossiliferous breccia.

autapomorphies of Asoriculus and Nesiotites with respect to their most recent common relative were minimal. Their results support the opinion of Reumer (1984), who considered Nesiotites as a very close relative or a direct descendant of Episoriculus. Masini and Sarà (1998), on the basis of a morphometric study, proposed that Nesiotites should be included in the genus Asoriculus, a view that has been followed by Furió (2007) and Bover and Alcover (2008). Van der Made (1999) suggests restricting the genus name for the Balearic taxa and to include the Corso-Sardinian species in Asoriculus, a point of view that has been followed by Van der Geer et al. (2010). All the authors agree with the strong relationship between the species placed in Nesiotites and Asoriculus.

Maul and Rzebik-Kowalska (1998) suggested that Asoriculus should be considered as the direct ancestor of Neomys Kaup, 1829. Nevertheless, the phylogenetic approach by Rofes and Cuenca-Bescós (2009) does not sustain this hypothesis.

In this paper, following Van der Made (1999) we maintain Nesiotites as a genus name restricted to the Balearic taxa, in order to avoid the previous polyphyletic interpretation. In this sense, Nesiotites similis and $N$. corsicanus will be referred to as Asoriculus similis and $A$. corsicanus from here on.

Asoriculus was present in the Mediterranean zone since the Late Miocene (Rofes and CuencaBescós, 2006). These authors give a detailed account of the great dispersion of Asoriculus in the European mainland and the Mediterranean Islands during the Late Miocene and the Plio-Pleistocene. Nesiotites should be considered as an insular derivative from, probably, Asoriculus gibberodon Petényi, 1864 (e.g., Kotsakis, 1980; Esu and Kotsakis, 1980; Reumer, 1984; Pons-Monjo et al., 2010).

In this context, the mandible of a soricid from Caló den Rafelino that we present in this paper is particularly interesting, not only for its early age, preceding all the previous records at the Balearic Islands, but also for its peculiar morphology and morphometrics. 


\section{The Site}

The fossiliferous bone breccia yielding the fossils here studied is located on the East coast of Mallorca, close to Caló den Rafelino, in the municipality of Manacor (Figure 2). The outcrop is very close to the seashore and consists of hardened red limestones of a collapsed cave gallery excavated in the Upper Miocene Reef Complex (Pomar et al., 1990; Fornós, 1998; Robledo and Pomar, 2000). This complex has a Late Tortonian-Messinian age (Bizon et al., 1973). Although red limestones are filling the whole collapsed gallery, the fossils are concentrated in a small area, about $1 \mathrm{~m}^{2}$ (Figure 2).

The stratigraphic and palaeontological evidence suggests an Early Pliocene age (Bover et al., 2007, 2010; Bailon et al., 2010; Quintana et al., 2010). Likely, the infilling was restricted to a very short period, posterior to the Tortonian-Messinian boundary and previous to Piacenzian (i.e., at the uppermost part of MN13 or at MN14). Some taxa recorded in Caló den Rafelino are not present in the later Mallorcan Pliocene deposits, while three of the mammals present at this site display intermediate characters between the fauna recorded at Cala Morlanda (MN15) and their putative mainland Miocene ancestors. The mammalian fauna of the deposit (Bover et al., 2007, 2010; Quintana, 2010) suggests that the colonization event occurred during the Messinian Salinity Crisis (5.6-5.32 Ma, according to Krijgsman et al., 1999). Consequently, an earliest Early Pliocene age (MN13-14) is suggested for the site. A detailed chronostratigraphical and biochronological framework is presented in Figure 1.

The faunal assemblage of Caló den Rafelino has not been previously recorded in Mallorca. In addition to the soricid studied herein, it contains remains of four other mammals (the caprine Myotragus palomboi Bover et al., 2010; the lagomorph Hypolagus balearicus, Quintana et al., 2010; a large-sized still not described new genus of cricetid, and a glirid of the genus Hypnomys Bate, 1918), several reptiles (Vipera sp. of the Oriental Vipers complex, Vipera aff. natiensis, a colubroid snake, a tortoise, a lacertid, and an anguid), a bird, and some fish teeth (Bover et al., 2007, 2010; Bailon et al., 2010; Quintana et al., 2010).

\section{Abbreviations}

Institutional: IMEDEA, Institut Mediterrani d'Estudis Avançats (CSIC-UIB); UZ, Universidad de Zaragoza.
Dental terminology and measurements: $p$, lower premolar; $\mathrm{m}$, lower molar; L, length; TRW, trigonid width; TAW, talonid width; $\mathrm{Hm1}$, height of mandible below $\mathrm{m} 1$ (medial side); $\mathrm{Hm} 2$, height of mandible below $\mathrm{m} 2$ (medial side).

\section{MATERIAL AND METHODS}

The specimen was extracted from the fossiliferous bone breccia through treatment with acetic acid, and it was posteriorly consolidated. More than $50 \mathrm{~kg}$ of breccia have been processed, and no additional shrew bones have been obtained. Although some breccia is still in the deposit, it seems that the fossiliferous part has been already collected and, thus, no additional material can be obtained.

We follow Reumer's (1984) anatomical nomenclature, with a few additions from Jin and Kawamura (1996), given its almost universal use among scholars dealing with fossil soricids from the Plio-Quaternary.

Metric values were recorded using a stereomicroscope (Olympus MSZH, objective 64x) connected to a video camera. We follow Reumer (1984) for measurements, with some additions from Rabeder (1972). For the morphometric analysis we used the PAST v2.01 statistical programme (Hammer et al., 2001).

\section{SYSTEMATIC PALAEONTOLOGY}

Class MAMMALIA Linnaeus, 1758

Order EULIPOTYPHLA Waddell, Okada and Hasegawa, 1999

Family SORICIDAE Fischer von Waldheim, 1817

Subfamily SORICINAE Fischer von Waldheim, 1817

Genus NESIOTITES Bate, 1945

NESIOTITES RAFELINENSIS sp. nov. Figure 3.1-3

Type locality and age. Caló den Rafelino, Manacor (Mallorca, Balearic Islands, Spain); earliest Early Pliocene (5.3-4.5 Ma, MN13-14).

Holotype. IMEDEA 91950, incomplete left mandible with $\mathrm{p} 4, \mathrm{~m} 1, \mathrm{~m} 2$, and $\mathrm{m} 3$.

Location of types. Holotype in the collection of the IMEDEA, Palma de Mallorca (Spain).

Etymology. Derived from the type locality, Caló den Rafelino.

Measurements $(\mathrm{mm}) . \mathrm{Lp} 4=1.46, \mathrm{Wp} 4=1.01$, $\mathrm{Lm} 1=1.93, \mathrm{TRWm} 1=1.1, \mathrm{TAWm} 1=1.22, \mathrm{Lm} 2=$ 1.72, TRWm2 = 1.16, TAWm2 = 1.1, Lm3 = 1.29, 


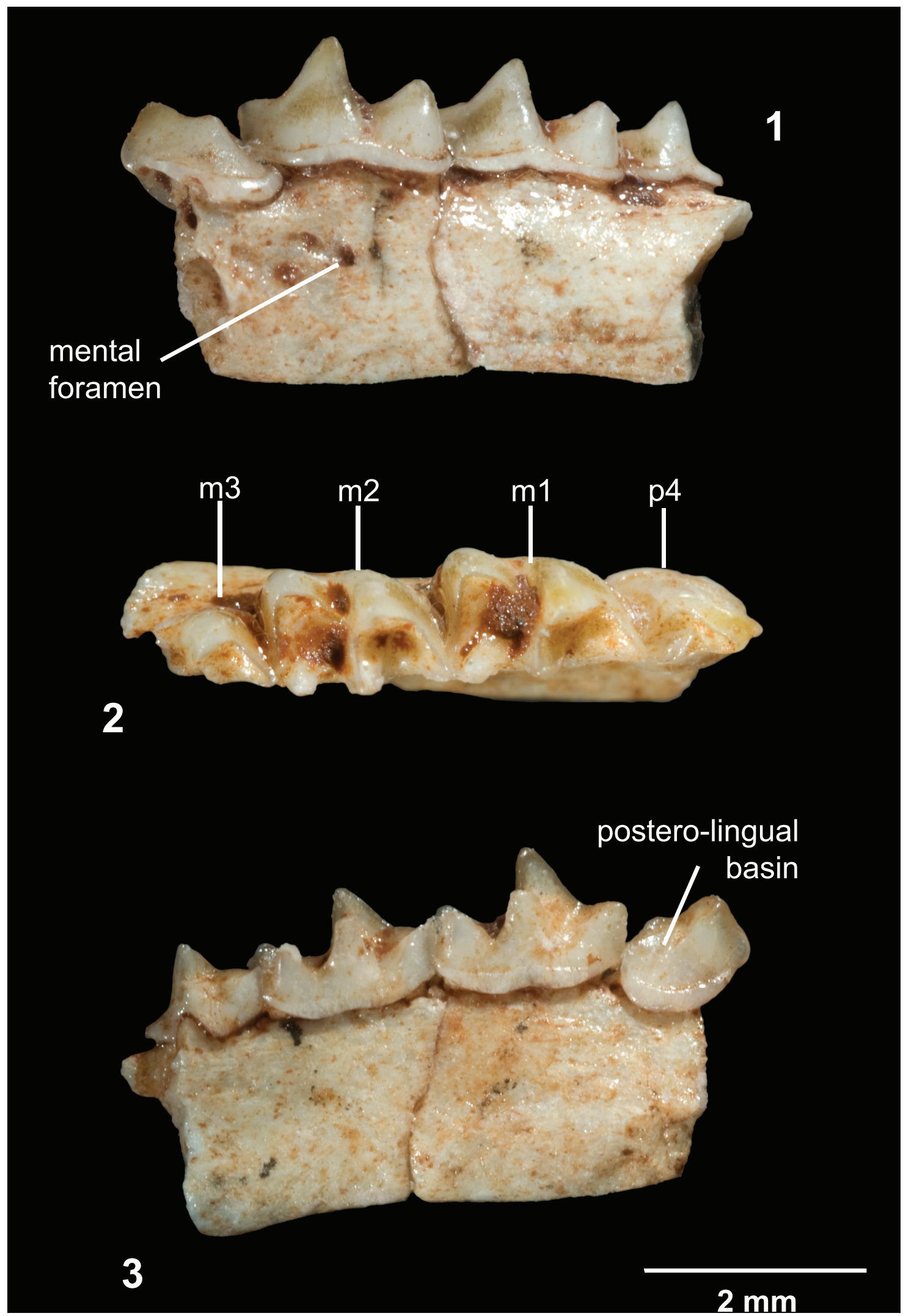

FIGURE 3. Nesiotites rafelinensis sp. nov. Holotype IMEDEA 91950, incomplete left mandible from the earliest Early Pliocene site of Caló den Rafelino, in (1) buccal, (2) occlusal, and (3) lingual views. 
$\mathrm{Wm} 3=0.73, \mathrm{Lm} 1-\mathrm{m} 3=4.68, \mathrm{Hm} 1=1.93, \mathrm{Hm} 2=$ 1.79 .

Diagnosis: Species of Nesiotites with teeth dimensions close to $N$. ponsi, but mandibular body as large as in $N$. aff. ponsi (from Pedrera de s'Ònix). It differs from N. ponsi, N. aff. ponsi, N. hidalgo, and Asoriculus similis in not having accessory cusps on the oblique crest of the first and second lower molars (as in A. gibberodon). The cuspule and lingual crest on the posterolingual basin of the $\mathrm{p} 4$ (absent in A. gibberodon) are not as conspicuous as in N. ponsi, N. aff. ponsi, or N. hidalgo. The buccal and lingual cingula of the lower teeth are comparatively broader and more pronounced than in all other Nesiotites species. The buccal cingulum of the lower molars is (as in A. gibberodon) not as undulated as in $N$. ponsi, N. aff. ponsi, and $N$. hidalgo. Teeth stained a light orange at the top of the crowns (as in A. gibberodon). Mental foramen placed slightly forward than in all other Nesiotites species.

\section{DESCRIPTION}

All the dental elements are supposed to be stained a light orange in the apical part of the crown. However, only a trace of the pigment remains at the very top of the crowns of the specimen, probably due to taphonomical reasons.

p4 (Figure 3.1-3). The occlusal outline is roughly triangular, although the posterior face is remarkably incurvated due to the elongation of the posterobuccal corner of the crown. Two main cusps are present on the crown. The anterior one is higher and lingually oriented in occlusal view. These two cusps are connected by a sharp, high ridge which encloses a posterolingual basin on its lingual side. This basin drains steeply posterolingually and exhibits a very low cuspule, connected to the anterior cusp by an also low lingual crest. A very thick cingulum is observed on the buccal base of the crown, where the crown hangs over the root. The lingual cingulum is also well developed but weaker than the buccal one.

m1-m2 (Figure 3.1-3). They have a trapezoidal shape in occlusal view and present five main cusps: the paraconid, protoconid, metaconid, entoconid, and hypoconid. They also have an accessory cusp, the entostylid. The three anterior cusps (para-, proto-, and metaconid) are connected by crests or ridges, forming the trigonid which is $\mathrm{V}$ shaped. The paralophid is longer than the protolophid. Each crest has a notch at its middle part. The protoconid is the highest cusp of the crown and is situated anterobuccally to the metaconid. From the hypoconid, the oblique crest descends anterolingually towards the protoconid, and attaches to its posterior face forming the hypoflexid, which steeply descends buccally almost reaching the buccal cingulum. Another ridge, the hypolophid, extends lingually from the hypoconid to the entostylid, which is tiny and almost indistinct. The entostylid is separated from the entoconid by a valley more widely opened on $\mathrm{m} 1$. The entoconid is an isolated conical cusp which connects to the posterior base of the metaconid by the entoconid crest. The latter is low on $\mathrm{m} 1$ and nearly absent on $\mathrm{m} 2$. The talonid is wider than the trigonid on $\mathrm{m} 1$. On $\mathrm{m} 2$ the talonid is slightly narrower. The lingual cingulum is broad but hardly pronounced. The buccal cingulum is broad, well developed and slightly undulated on $\mathrm{m} 2$.

$\mathrm{m} 3$ (Figure 3.1-3). The occlusal outline is semicircular. The trigonid is smaller but basically similar to those of the first two molars. The talonid is markedly reduced, so that the talonid basin is much smaller and shallower than the trigonid basin. Unfortunately, the posterior half of the talonid is not preserved. The buccal cingulum is well developed, while the lingual one is weaker.

Mandible (Figure 3.1, 3.3). The mandibular body is stoutly built. The mental foramen is placed below the hypoflexid of the first lower molar.

\section{MORPHOMETRIC ANALYSIS}

The elements included in the analysis are both dental and mandibular, namely: $\mathrm{m} 1, \mathrm{~m} 2, \mathrm{~m} 3$, and the mandibular body. The measurements used as variables were: length $(L)$ and talonid width (TAW) for the lower molars; and height $(\mathrm{H})$ for the mandible.

We compared the specimen from Caló den Rafelino (CDR from here on) with all the species of Nesiotites and Asoriculus that have these measurements available from reference collections (IMEDEA, UZ), and from the literature (Table 1). In the case of Asoriculus gibberodon we took the average values of the measurements published for three sites (see legend of Figure 4).

Figure 4 shows the results of the bivariate analysis carried out with the $L$ and TAW measurements of $m 1$ (see above). The specimen from CDR falls very close to the polygon (nearly a segment) that includes the Nesiotites ponsi available specimens. It also falls inside the $95 \%$ confidence ellipse of Nesiotites aff. ponsi, but relatively far from the convex hull of this taxon. CDR m1's dimensions are closer to Asoriculus thenii Malez 
TABLE 1. Measurements of the mandible and lower teeth of the Nesiotites and Asoriculus specimens used in the morphometric analysis. Lm1, length of $\mathrm{m} 1$; TAWm1, talonid width of $\mathrm{m} 1 ; \mathrm{Hm} 2$, height below $\mathrm{m} 2$; Lm1-m3, length of $\mathrm{m} 1$ to m3.

\begin{tabular}{|c|c|c|c|c|c|c|}
\hline Species & Site & Age & Lm1 & TAWm1 & $\mathrm{Hm} 2$ & Lm1-m3 \\
\hline $\begin{array}{l}\text { Nesiotites rafelinensis } \\
\text { sp. nov. }\end{array}$ & $\begin{array}{l}\text { Caló den } \\
\text { Rafelino }\end{array}$ & Early Pliocene & 1.93 & 1.22 & 1.79 & 4.68 \\
\hline \multirow[t]{4}{*}{ Nesiotites ponsi } & $\begin{array}{l}\text { Cruis de Cap } \\
\text { Farrutx }\end{array}$ & Late Pliocene & 1.88 & 1.22 & 1.69 & 4.63 \\
\hline & & & 1.8 & 1.19 & 1.61 & 4.3 \\
\hline & & & 1.95 & 1.24 & 1.65 & 4.47 \\
\hline & & & 1.88 & 1.22 & 1.65 & 4.47 \\
\hline \multirow[t]{6}{*}{ Nesiotites aff. ponsi } & $\begin{array}{l}\text { Pedrera de } \\
\text { s'Onix }\end{array}$ & Early Pleistocene & 2.1 & 1.32 & 2.02 & 4.93 \\
\hline & & & 1.9 & 1.3 & 1.79 & 4.76 \\
\hline & & & 2.1 & 1.34 & 1.9 & 5.05 \\
\hline & & & 2.14 & 1.28 & 2.03 & 5 \\
\hline & & & 2.11 & 1.33 & 1.93 & 4.95 \\
\hline & & & 2.14 & 1.26 & 2.02 & 5.12 \\
\hline Nesiotites meloussae & $\begin{array}{l}\text { Barranc de } \\
\text { Binigaus }\end{array}$ & Early Pleistocene & 2.11 & 1.54 & 1.99 & 5.31 \\
\hline \multirow[t]{9}{*}{ Nesiotites hidalgo } & $\begin{array}{l}\text { Cova de } \\
\text { Llenaire }\end{array}$ & Late Pleistocene & 2.27 & 1.39 & 2.07 & 5.43 \\
\hline & & & 2.14 & 1.36 & 1.93 & 5.2 \\
\hline & & & 2.4 & 1.4 & 1.92 & 5.47 \\
\hline & Cova Estreta & Late Pleis/Holocene & 2.37 & 1.51 & 1.96 & 5.63 \\
\hline & & & 2.39 & 1.5 & 2.17 & 5.58 \\
\hline & & & 2.37 & 1.43 & 1.94 & 5.56 \\
\hline & Cova de Canet & Late Pleis/Holocene & 2.23 & 1.48 & 1.94 & 5.47 \\
\hline & & & 2.32 & 1.47 & 2.02 & 5.5 \\
\hline & & & 2.35 & 1.44 & 2.16 & 5.63 \\
\hline \multirow[t]{3}{*}{ Asoriculus similis } & Sardinia & Late Pleistocene & 2.23 & 1.23 & 1.67 & 5.11 \\
\hline & & & 2.32 & 1.32 & 1.66 & 5.29 \\
\hline & & & 2.31 & 1.33 & 1.76 & 5.34 \\
\hline \multirow[t]{3}{*}{ Asoriculus gibberodon } & Vceláre 3 & Late Pliocene & 1.42 & 0.9 & 1.35 & 3.7 \\
\hline & Monte La Mesa & Early Pleistocene & 1.58 & 1.02 & 1.54 & 3.64 \\
\hline & $\begin{array}{l}\text { Sima del } \\
\text { Elefante }\end{array}$ & Early Pleistocene & 1.6 & 0.97 & 1.41 & 3.92 \\
\hline \multirow[t]{2}{*}{ Asoriculus thenii } & Podumci 1 & Early Pleistocene & 1.71 & 1.08 & 1.87 & 4.19 \\
\hline & Tatinja Draga & Early Pleistocene & 1.86 & 1.12 & 1.99 & 4.46 \\
\hline
\end{tabular}

and Rabeder, 1984, than they are to Asoriculus gibberodon, A. similis, Nesiotites hidalgo, and the single available $N$. meloussae.

According to the plot, the $\mathrm{m} 1$ of CDR has almost the same size and shape than that of $N$. ponsi. Altogether, Nesiotites species have a wider talonid (TAW) than continental Asoriculus. Nesio- tites meloussae has the widest talonid of the whole sample.

The principal components analysis (PCA) (Figure 5) carried out with the measurements of the lower teeth and the mandible (see Table 1) shows a closer morphometric affinity of the CDR specimen with $N$. aff. ponsi than with $N$. ponsi, even though it also falls inside the $95 \%$ confidence 


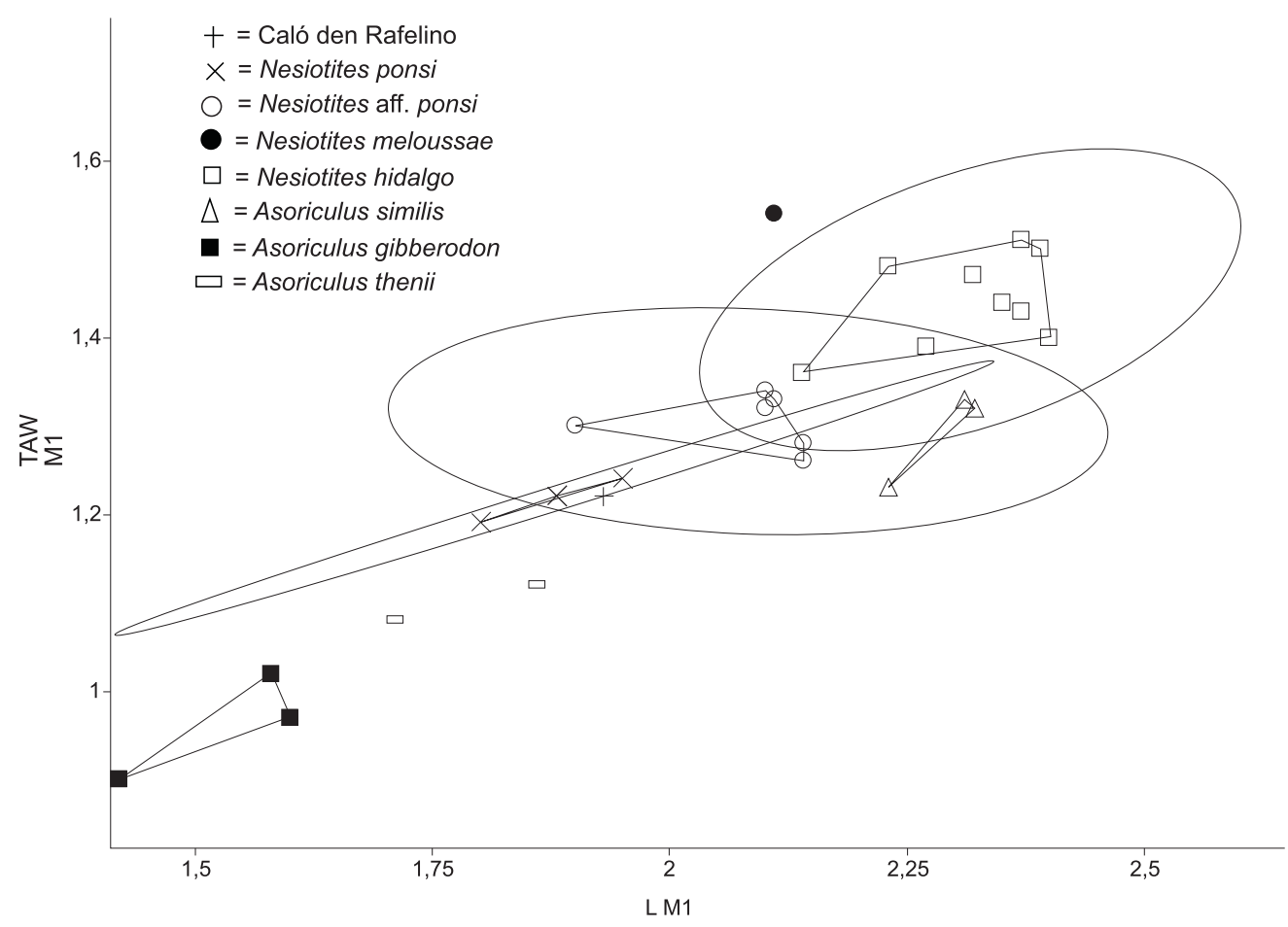

FIGURE 4. Bivariate diagram of the m1's $L$ and TAW measurements. Measurements of Asoriculus gibberodon taken from Fejfar and Horácek (1983), Marchetti et al. (2000), and Rofes and Cuenca-Bescós (2006). Measurements of Asoriculus thenii taken from Malez and Rabeder (1984). Nesiotites ponsi specimens are from the site of Cruis de Cap Farrutx, Mallorca (Late Pliocene); Nesiotites aff. ponsi specimens from Pedrera de s'Onix, Mallorca (Early Pleistocene); Nesiotites hidalgo specimens from Cova de Llenaire, Cova de Canet, and Cova Estreta, Mallorca (Late Pleistocene/Holocene); N. meloussae specimen from Barranc de Binigaus, Menorca (Early Pleistocene); Asoriculus similis specimens from Sardinia (Late Pleistocene); Asoriculus gibberodon specimens from Vceláre 3, Slovakia (Late Pliocene), Monte La Mesa, Italy (Early Pleistocene), and Sima del Elefante, Spain (Early Pleistocene); Asoriculus thenii specimens from Podumci 1 and Tatinja Draga, Croatia (Early Pleistocene). Convex hulls, distribution; Ellipses, $95 \%$ confidence.

ellipses of both. A closer look at the loads of the PCA variables reveals that they are very similar on PC1 (Table 2), a sure sign that the first axis represents size. PC1 explains $88.38 \%$ of the global variance. On PC2, by contrast, the contribution of $\mathrm{Hm} 2$ is clearly greater (Table 2). PC2 should have a higher morphological load, explaining the $8.49 \%$ of the variance.

It is noteworthy to say that the morphometric distance between the CDR item and $N$. ponsi is also rather short. In fact, it is less than the intraspecific variability recorded for all the samples except for $N$. ponsi, which is indeed peculiar in having a very limited variation.

It must be said that the results of the PCA are guiding more than conclusive, due to the restricted number of items of some taxa (i.e., CDR, N. meloussae, $A$. thenii).

Even though, the combined results of both bivariate and multivariate (PCA) analyses are consistent with the assignation of the CDR specimen to a new species with primitive dental features and closer in dental dimensions to $N$. ponsi, although with a mandibular body size close to $N$. aff. ponsi.

\section{SIZE AND CHRONOLOGY}

Differentiating among fossil species of the genus Nesiotites has involved classic size differences. There is a clear evolutionary trend of increase of size from Nesiotites ponsi, the earliest species known to date (Late Pliocene) to Nesiotites hidalgo, from the Pleistocene-Holocene (e.g., Reumer, 1980). As previously mentioned, Nesiotites aff. ponsi (Nesiotites ex. interc. ponsi-hidalgo, sensu Reumer, 1981) from the Early Pleistocene is a form intermediate in size.

In this evolutionary trend towards larger size, where the purported ancestor of the genus Nesiotites, namely Asoriculus gibberodon (Reumer, 1984; Masini and Sarà, 1998; Van der Made, 1999; Rofes and Cuenca-Bescós, 2009; Pons-Monjo et 


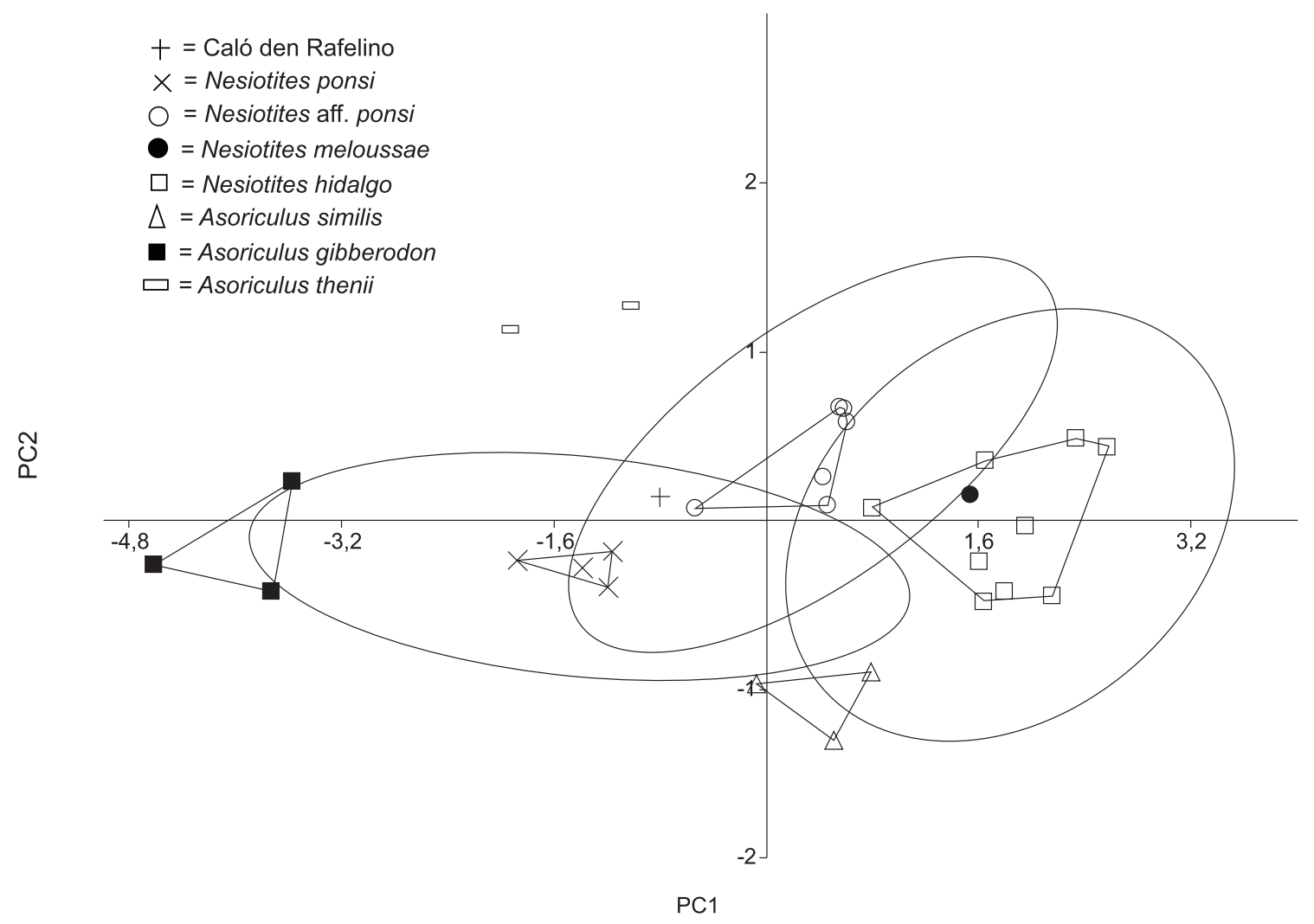

FIGURE 5. Principal component analysis (PCA) showing plot of components 1 against 2 . Measurements of the lower teeth and the mandible used: Lm1, TAWm1, Hm2, and Lm1-m3. Measurements of Asoriculus gibberodon and A. thenii taken from the same sources as in Figure 4. Specimens other than that of Calo den Rafelino are from the same locations as in Figure 4. Details can be found in Table 2. Convex hulls, distribution; Ellipses, 95\% confidence.

al., 2010; Van der Geer, 2010), is considerably smaller than Nesiotites ponsi (see Figures 4, 5), the mandibular body height and robustness of the specimen from Caló den Rafelino, similar to that of Nesiotites aff. ponsi, is unexpected. If we take into account that the taxon from Caló den Rafelino is considerably older than the earliest remains of Nesiotites found to date (i.e., earliest Early Pliocene versus Late Pliocene, respectively; see Table 1 ), we can say that it possibly breaks a otherwise regular trend.

\section{DISCUSSION}

The morphological features displayed by the single Nesiotites specimen obtained from Caló den Rafelino are, in our opinion, strong enough to differentiate it from the species of Nesiotites described until now. Nesiotites rafelinensis sp. nov. represents the most primitive species of the genus, close to its putative mainland ancestor Asoriculus gibberodon.

Pons-Monjo et al. (2010) highlight the uncertainty of the "presence/absence of accessory cusps" on the first and second lower molars as a valid feature to discriminate among the different forms of the genus. The presence of those accessory cuspules in Asoriculus similis argues in favour of its ambiguous nature (JR, personal observation). In this regard, we want to emphasize that, although we include this trait in the diagnosis, we do not rely exclusively on it to define a new species, but on the combination of a set of characters instead (see

TABLE 2. Results of the PCA performed with the measurements of the mandible and the lower dentition. Jolliffe cut-off: 0.7 .

\begin{tabular}{lcccc}
\hline & PC1 & PC2 & PC3 & PC4 \\
\hline Eigenvalue & 3.535 & 0.339 & 0.109 & 0.017 \\
\% variance & 88.376 & 8.487 & 2.717 & 0.420 \\
\hline Loadings & & & & \\
L m1 & 0.510 & -0.364 & 0.527 & 0.574 \\
TAW m1 & 0.510 & -0.154 & -0.822 & 0.204 \\
H m2 & 0.456 & 0.88 & 0.127 & 0.037 \\
L m1-m3 & 0.522 & -0.263 & 0.176 & -0.792 \\
\hline
\end{tabular}


above). The general appearance of the lower teeth of the specimen from Caló den Rafelino does not substantially differ from that of Nesiotites, but it has certain features that relate it more with $A$. gibberodon than any other representative of the genus.

$N$. rafelinensis combines primitive dental traits with a relatively large size. Its size is greater than that of Asoriculus gibberodon and Nesiotites ponsi. The new species is also morphometrically closer to the $A$. gibberodon items from Spain (Sima del Elefante) and Italy (Monte La Mesa) than to those from central Europe (Vceláre 3).

The evolution of body size in the Mallorcan shrews involved an initial size increase (from the presumed ancestor $A$. gibberodon to $N$. rafelinensis), followed by a size decrease (from $N$. rafelinensis to $N$. ponsi), to increase again size later (from $N$. ponsi to $N$. hidalgo). The size of $N$. rafelinensis breaks a regular trend from Asoriculus gibberodon to $N$. hidalgo. Size decreasing coeval the disappearance of most of the taxa present in Caló den Rafelino, and possibly both phenomena (i.e., size decreasing of shrews and disappearance of most of the taxa) could be related to the same unknown causes.

It should be noticed that although Nesiotites rafelinensis have a size closer to Asoriculus thenni (see Figures 4, 5), an endemism of Croatia (Malez and Rabeder, 1984), than to $A$. gibberodon, a direct phylogenetic relationship between the Mallorcan and Croatian species seems unlikely due to chronological and biogeographical constrains (see Rofes and Cuenca-Bescós, 2006).

Besides $N$. rafelinensis, the faunal assemblage from Caló den Rafelino includes the first representatives of the genera Myotragus (i.e., $M$. palomboi) and Hypolagus (i.e., H. balearicus) of the Balearic Islands, together with a new genus of cricetid, and a species of Hypnomys (Gliridae) that remain to be described (Bover et al., 2008, 2010; Quintana et al., 2010). Also it has the earliest fossil record of Vipera from the western Mediterranean Islands (Bailon et al., 2010). All these endemic taxa show the anatomical effects of insularity to a greater or a lesser extent. The relatively large size and morphological peculiarities of $N$. rafelinensis could be no exception in this sense. Altogether, the faunal assemblage of this deposit represents the earliest evidence of the fauna that arrived to the Mallorca Island during the Messinian Salinity Crisis.

\section{ACKNOWLEDGMENTS}

Juan Rofes has a "Juan de la Cierva" postdoctoral contract (JCl-2010-06148) of the Ministerio de Ciencia e Innovación (Spain). Pere Bover has a contract JAE-DOC (CSIC) of the program "Junta para la Ampliación de Estudios". This paper is included in the Project CGL2010-17889 of the Dirección General de Investigación (Ministerio de Educación y Ciencia, Spain). Thanks to the Atapuerca Project, CGL2009-12703-C03-03 of the Ministerio de Ciencia e Innovación, for the financial support. Two anonymous referees helped considerably to improve the manuscript.

\section{REFERENCES}

Agustí, J., Cabrera, L., Garcés, M., Krijgsman, W., Oms, O., and Parés, J.M. 2001. A calibrated mammal scale for the Neogene of Western Europe. State of the art. Earth-Science Reviews, 52:247-260.

Alcover, J.A., Moyà-Solà, S., and Pons-Moyà, J. 1981. Les quimeres del passat. Els vertebrats fòssils del Plio-Quaternari de les Balears i Pitiüses. Moll, Palma de Mallorca.

Bailon, S., Bover, P., Quintana, J., and Alcover, J.A. 2010. First fossil record of Vipera Laurenti 1768 "Oriental vipers complex" (Serpentes: Viperidae) from the Early Pliocene of the Western Mediterranean Islands. Comptes Rendus Palevol, 9:147-154.

Bate, D.M.A. 1918. On a new genus of the extinct muscardine rodent from the Balearic Islands. Proceedings of the Zoological Society London, 88(3-4):209222.

Bate, D.M.A. 1945. Pleistocene shrews from the larger Western Mediterranean Islands. The Annals and Magazine of the Natural History Series, 11:738-769.

Bizon, G., Bizon, J.J., Bourrouilh, R., and Massa, D. 1973. Présence aux îles Baléars (Méd. Occ.) de sédiments "Messiniens" déposés dans une mer ouverte, à salinité normale. Comptes Rendus de l'Académie des Sciences de Paris, 277:8-985.

Blyth, E. 1854. Report of Curator, Zoological Department, for September, 1854. Journal of the Asiatic Society of Bengal, 23:729-740.

Bover, P. and Alcover, J.A. 2008. Extinction of the autochthonous small mammals of Mallorca (Gymnesic Islands, Western Mediterranean) and its ecological consequences. Journal of Biogeography, 35:1112-1122.

Bover, P., Quintana, J., and Alcover, J.A. 2008. Three islands, three worlds: Paleogeography and evolution of the vertebrate fauna from the Balearic Islands. Quaternary International, 182:135-144.

Bover P., Quintana, J., and Alcover, J.A. 2010. A new species of Myotragus Bate, 1909 (Artyodactyla, Caprinae) from the Early Pliocene of Mallorca (Balearic Islands, western Mediterranean). Geological Magazine, 147:871-885. 
Bover, P., Quintana, J., Agustí, J., Bailon, S., and Alcover, J.A. 2007. Caló den Rafelino: an Early Pliocene site in Mallorca, Western Mediterranean. In Libro de resúmenes del VII Simposio Internacional de Zoología, 119. Topes de Collantes, Cuba.

Ellerman, J.R. and Morrison-Scott, T.C.S. 1951. Checklist of Palaeartic and Indian mammals 1758-1946. British Museum (Natural History), London.

Esu, D. and Kotsakis, T. 1980. Paleobiogeografia dei vertebrati e dei molluschi continentali del Terziario e del Quaternario della Sardegna. Lavori della Società Italiana di Biogeografia, 8:53-82.

Fejfar, O. and Horácek, I. 1983. Zur Entwicklung der Kleinsäugerfaunen im Villányium und Alt-Biharium auf dem Gebiet der CSSR, p. 111-207. In Heinrich, W.-D. (ed.), Wirbeltier-Evolution und Faunenwandel im Känozoikum, 19-20. Schriftenreihe für Geologische Wissenschaften. Akademie-Verlag, Berlin.

Fischer von Waldheim, G. 1817. Adversaria Zoologica. Mémoires de la Societé Impériale des Naturalistes de Moscou, 5:368-428.

Fornós, J.J. 1998. Karst collapse phenomena in the Upper Miocene of Mallorca (Balearic Islands, Western Mediterranean). Acta Geologica Hungarica, 42:237-250.

Furió, M. 2007. Los insectívoros (Soricomorpha, Erinaceomorpha, Mammalia) del Neógeno Superior del Levante Ibérico. Unpublished PhD Thesis, Universitat Autònoma de Barcelona, Spain. Available at: www.tesisenred.net/bitstream/handle/10803/3446/ mfb1de1.pdf?sequence=1

Gibbard, P.L., Head, M.J., Walker, M.J.C. and the Subcommission on Quaternary Stratigraphy. 2010. Formal ratification of the Quaternary System/Period and the Pleistocene Series/Epoch with a base at 2.58 Ma. Journal of Quaternary Science, 25:96-102.

Hammer, Ø., Harper D.A.T., and Ryan P.D. 2001. PAST: Paleontological Statistics Software Package for Education and Data Analysis. Version 2.01. Palaeontologia Electronica, 4(1):9p, 3.76 MB. folk.uio.no/ ohammer/past/.

Hensel, R.F. 1855. Beiträge zur Kenntniss fossiler Säugethiere Insectenfresser und Nagethiere der Diluvialformation. Zeitschrift der Deutschen Geologischen Gesellschaft, 7:458-501.

Hutterer, R. 1994. Generic limits among neomyine and soriculine shrews (Mammalia: Soricidae), p. 32. In Neogene and Quaternary mammals of the Paleartic, conference in honour of Professor Kazimierz Kowalski, Abstracts. Kraków.

Jin, Ch. and Kawamura, Y. 1996. The first reliable record of Beremendia (Insectivora, Mammalia) in East Asia and a revision of Peisorex Kowalski and Li, 1963. Transactions and Proceedings of the Palaeontological Society of Japan, N.S., 182:432-447.

Kaup, J.J. 1829. Skizzirte Entwickelungsgeschichte und natürliches System der Europäischen Thierwelt. C.W., Leske, Darmstadt.
Kotsakis, T. 1980. Osservazioni sui vertebrati quaternari della Sardegna. Bolletino della Società Geologica Italiana, 99:151-165.

Kretzoi, M. 1959. Insectivores, rodents and lagomorphs of the Early Pleistocene fauna of Csarnóta in the Villány area (South Hungary). Vertebrata Hungarica, 1:237-246.

Krijgsman, W., Hilgen, F.J., Raffi, I., Sierro, F.J., and Wilson, D.S. 1999. Chronology, causes and progression of the Messinian salinity crisis. Nature, 400:652-655.

Linnaeus, C. 1758. Systema naturae per regna tria naturae, secundum classes, ordines, genera, species, cum characteribus, differentiis, synonymis, locis. Vol. 1: Regnum animale. Editio decima, reformata. Laurentii Salvii, Stockholm.

Malez, M. and Rabeder, G. 1984. Neues Fundmaterial von Kleinsäugern aus der altpleistozänen Spaltenfüllung Podumci 1 in Norddalmatien (Kroatien, Jugoslawien). Beiträge zur Paläontologie von Österreich, 11:439-510.

Marchetti, M., Parolin, K., and Sala, B. 2000. The Biharian fauna from Monte La Mesa (Verona, north-eastern Italy). Acta Zoologica Cracoviensia, 43:79-105.

Masini, F. and Sarà, M. 1998. Asoriculus burgioi sp. nov. (Soricidae, Mammalia) from the Monte Pellegrino faunal complex (Sicily). Acta Zoologica Cracoviensia, 41:111-124

Maul, L. and Rzebik-Kowalska, B. 1998. A record of Macroneomys brachygnathus Fejfar, 1966 (Mammalia, Insectivora, soricidae) in the early Middle Pleistocene (Late Biharian) locality of Voigtstedt (Germany) and the history of the genus Macroneomys. Acta Zoologica Cracoviensia, 41:79-100.

Petényi, S.J. 1864. A beremendi mészkobánya természetrajzés öslénytanilag leírva. Hátrahagyott Munkái Magyar Tudományos Akademia, 1:35-81.

Pomar, L., Rodríguez-Perea, A., Sabat, F., and Fornós, J.J. 1990. Neogene stratigraphy of Mallorca Island. Paleontologia i Evolució, 2:271-320.

Pons-Monjo, G., Furió, M., and Moyà-Solà, S. 2010. The genus Nesiotites (Soricidae, Insectivora, Mammalia) in the Balearic Islands: state of the art. Cidaris, 30:253-258

Pons-Moyà, J. 1990. Estratigrafía y fauna del yacimiento kárstico de Cala Morlanda (Manacor, Mallorca). Endins, 16:59-62.

Pons-Moyà, J. and Moyà-Solà, S. 1980. Nuevo representante del género Nesiotites Bate, 1944; Nesiotites meloussae nov. sp. (Insectivora. Soricidae) de los rellenos cársticos del Barranc de Binigaus (Es Mercadal, Menorca). Endins, 7:53-56.

Quintana, J., Bover, P., Alcover, J.A., Agustí, J., and BaiIon, S. 2010. Presence of Hypolagus Dice, 1917 (Mammalia, Lagomorpha) in the Neogene of the Balearic Islands (Western Mediterranean): Description of Hypolagus balearicus nov. sp. Geobios, 43:555-567. 
Rabeder, G. 1972. Die Insectivoren und Chiropteren (Mammalia) aus dem Altpleistozan von Hundsheim (Niederosterreich). Annalen des Naturhistorischen Museums in Wien, 76:375-474.

Reumer, J.W.F. 1979. On two new micromammals from the Pleistocene of Mallorca. Proceedings of the Koninklijke Nederlandse Akademie van Wetenschappen, Series B, 82:473-482.

Reumer, J.W.F. 1980. On the Pleistocene shrew Nesiotites hidalgo Bate, 1944 from Majorca (Soricidae, Insectivora). Proceedings of the Koninklijke Nederlandse Akademie van Wetenschappen, Series $B$, 83:38-68.

Reumer, J.W.F. 1981. The Pleistocene mammals from Sa Pedrera de S'Onix, Majorca (Gliridae, Soricidae). Proceedings of the Koninklijke Nederlandse Akademie van Wetenschappen, Series B, 84:2-11.

Reumer, J.W.F. 1982. Some remarks on the fossil vertebrates from Menorca, Spain. Proceedings of the Koninklijke Nederlandse Akademie van Wetenschappen, Series $B$, 85:77-87.

Reumer, J.W.F. 1984. Ruscinian and Early Pleistocene Soricidae. Geological Survey Professional Paper, 565:1-74.

Reumer, J.W.F. 1998. A classification of the fossil and recent shrews, p. 5-22. In Wójcik, J.M. and Wolsan M. (eds.), Evolution of shrews. Mammal Research Institute, Polish Academy of Sciences, Bialowieza.
Robledo, P. and Pomar, L. 2000. Upper Miocene karst collapse structures of the East Coast, Mallorca, Spain. Acta Carsologica, 29:84-177.

Rofes, J. and Cuenca-Bescós, G. 2006. First evidence of the Soricidae (Mammalia) Asoriculus gibberodon (Petényi, 1864) in the Pleistocene of North Iberia. Rivista Italiana di Paleontologia e Stratigrafia, 112:301-315.

Rofes, J. and Cuenca-Bescós, G. 2009. A new genus of red-toothed shrew (Mammalia, Soricidae) from the Early Pleistocene of Gran Dolina (Atapuerca, Burgos, Spain), and a phylogenetic approach to the Eurasiatic Soricinae. Zoological Journal of the Linnean Society, 155:904-925.

Van der Made, J. 1999. Biogeography and stratigraphy of the Mio-Pleistocene mammals of Sardinia and the description of some fossils. In Reumer, J.W.F. and De Vos, J., (eds.), Elephants have snorkel! Papers in honour of Paul Y. Sondaar. Deinsea, 7:337-360.

Van der Geer, A., Lyras, G., De Vos, J., and Dermitzakis, M. 2010. Evolution of island mammals. Adaptation and extinction of placental mammals on Islands. Wiley-Blackwell, London.

Waddell, P.J., Okada, N., and Hasegawa, M. 1999. Towards resolving the interordinal relationships of placental mammals. Systematic Biology, 48:1-5. 